\title{
Livelihoods Limitations: The Political Economy of Urban Poverty in Dhaka, Bangladesh
}

\section{Nicola Banks}

\begin{abstract}
Research in Bangladesh reveals the limitations of actor-oriented frameworks for understanding urban poverty that assess household livelihoods on the basis of a household's portfolio of assets or capitals. The narrow focus of these frameworks on households and their depoliticized definition of social capital overlook the political roots of urban poverty. The informal systems of governance that dominate resource distribution within low-income settlements ensure that the social resources necessary for long-term household improvement are confined to a small elite. Only through extending our analysis beyond the household level, to explore their position within this local political economy of employment and enterprise, can we recognize the limitations placed on household efforts to improve their livelihoods.
\end{abstract}

\section{INTRODUCTION}

The nature of poverty in the global South is changing. It has been evident for some time that the urbanization of poverty is gaining increasing significance. This requires a shift for policy makers, planners and researchers who have spent decades focusing on rural development and livelihoods. Across many countries, including Bangladesh, previous development priorities have led to a rural bias in policy, action and research on poverty reduction, ${ }^{1}$ weakening

This is an open access article under the terms of the Creative Commons Attribution License, which permits use, distribution and reproduction in any medium, provided the original work is properly cited.

Nicola Banks is an ESRC Future Research Leader funded under grant reference number ES/K009729/1. She would like to thank colleagues at the University of Manchester for comments on an earlier draft, in particular Diana Mitlin and David Hulme. She would especially like to thank three anonymous reviewers for their helpful and critical comments that have helped to substantially strengthen the paper, and the Editorial Board for facilitating this process. Finally, she would like to thank the residents of the four communities that welcomed her so warmly.

1. This is in contrast to national development planning and policy, which displays an urban bias. Antagonism between elite and professional notions of 'urban development' and the

Development and Change 00(0): 1-27. DOI: 10.1111/dech.12219

(C) 2015 The Authors. Development and Change published by John Wiley \& Sons Ltd on behalf of International Institute of Social Studies. 
the conceptual tools for imagining poverty reduction in urban areas (Banks et al., 2011; de Haan, 1997; Jha et al., 2007; Mitlin and Satterthwaite, 2013).

The narrow ways in which urban poverty is conceived, defined and measured have led to urban poverty being misrepresented and underestimated (Mitlin and Satterthwaite, 2013; Satterthwaite and Mitlin, 2014). This leaves our understanding of urban poverty incomplete, centred around its visible experiences and consequences. These include poor quality housing, service provision, living environments and health outcomes. Its deeper roots including the political economy that creates and reproduces urban poverty - have in the process been overlooked (Beall, 1995; Jones and Corbridge, 2010). Deepening our understanding of urban poverty requires bridging the divide between actor-oriented frameworks for understanding urban poverty and political economic analyses that explore its political roots. The findings here reinforce research into rural livelihoods in Bangladesh, illustrating that incorporating the local political economy into our understanding of poverty allows us to see how inequalities are maintained through hierarchical forms of authority and power (Wood, 2005).

This analysis brings together otherwise disparate literatures on local urban governance and political participation (Banks, 2008; Jha et al., 2007; Pryer, 2003; Wratten, 1995) with research into urban livelihoods (Beall, 1995; Moser, 1998; Pryer, 2003; Rakodi, 1995). It also fills in a critical gap in the livelihoods literature, applying critiques of livelihoods frameworks (de Haan and Zoomers, 2005; Scoones, 2009; Wood, 2005) to an urban setting. In reconciling the relative roles of agency and structural constraints on poverty outcomes among the urban poor in Dhaka, it highlights that poverty goes beyond a lack of income and assets. Political inequalities at the settlement level create, maintain and exacerbate poverty and inequality. These inequalities allow a small elite to dominate resource distribution among low-income urban households, restricting access to the most valuable social resources that support social and economic advancement.

The following two sections locate this investigation within the literature on urban poverty and livelihoods, and introduce the research methodology. The remaining sections then explore urban livelihoods in Dhaka, examining how the local political economy of employment and enterprise influences household strategies and outcomes, and discussing the implications of these findings on actor-oriented frameworks for understanding urban poverty.

experiences of large segments of the urban population create a further obstacle to policy attention for urban poverty. Urban development is typically perceived to encompass processes of formalized planning, modernization, growth and wealth creation - processes and investments that increase and exacerbate inequality rather than catalyse poverty reduction. The repercussions of this for the urban poor go beyond the lengthy wait for benefits to 'trickle down' to them. Their presence, their informality, their living conditions and their struggle for rights to land, housing and services are at odds with such a vision of urban development. 


\section{UNDERSTANDING POVERTY IN URBAN CONTEXTS}

Urban poverty in the global South began to be rigorously conceptualized in the mid- to late-1990s, with research distinguishing how urban poverty is different to that in rural areas (Amis, 1995; de Haan, 1997; Wratten, 1995) and building new conceptual frameworks that recognized its multidimensional nature and the strategies that urban households deploy to cope and advance their interests (Beall, 1995; Meikle et al., 2001; Moser, 1998; Rakodi, 1995, 1999; Wratten, 1995). Wood (2005) discusses how the study of poverty has evolved towards a wider discourse on livelihoods. The urban literature has borrowed extensively from the rural sector, including concepts of 'livelihoods', 'vulnerability', 'capabilities' and 'assets', and in its use of participatory methods and critiques of poverty lines (Amis, 1995). Carney's (1998) Sustainable Rural Livelihoods framework has been adapted specifically for application in urban areas (e.g. Farrington et al., 2002; Meikle et al., 2001). Consistent across these frameworks is a focus on the household as the unit of analysis and the role of a diverse portfolio of 'assets' (Moser, 1998), 'capitals' (Bebbington, 1999; Carney, 1998; Wood and Salway, 2000), or 'endowments' (Pryer, 2003). This mixture of physical, natural, human, financial and social capitals provides an asset base through which low-income households can reduce risk and secure their livelihoods; for some, they provide a platform for escaping poverty.

Actor-oriented frameworks offer distinct advantages. They are amenable to policy recommendations and quantifiable indicators that can measure and track poverty (Carter, 2007; Farrington et al., 2002). They also have limitations. Carter hints at these when he explains that 'asset indicators have been used to provide a more detailed characterization of the poor' (2007: 59 , emphasis added). While providing insight into household experiences of urban poverty, actor-oriented frameworks overlook poverty's political roots and therefore the central obstacles faced by households in overcoming it. Despite the role that livelihoods strategies play in survival and 'getting ahead', the reality is that structural obstacles influence household decision making and limit the urban poor's choice of alternative coping strategies (Beall and Kanji, 1999; van Dijk, 2011; Wood and Salway, 2000). A critical factor in this is the local political economy of urban poverty that results in the uneven distribution of access to assets across poor households (Devas, 2001; Meikle et al., 2001; Wratten, 1995).

This is not to say that urban livelihoods research has taken place outside the urban context and the social, political and economic structures and institutions within it. Actor-oriented frameworks recognize that livelihoods strategies are shaped by the constraints under which households operate. They contextualize livelihoods strategies within the broader context of mesoand macro-level structures and warn that a narrow focus on households and strategies may overestimate the agency of poor households (Farrington et al., 2002; de Haan, 2012; de Haan and Zoomers, 2005; Meikle et al., 
2001; Moser, 1998; Rakodi, 1999; Scoones, 2009). Attempts to incorporate social and political capital into the livelihoods literature symbolize the efforts made to include the structural environments in which households seek sustainable livelihoods. ${ }^{2}$ Yet few analyses give sufficient attention to the influence of local power and politics and how these shape and constrain livelihood opportunities for low-income households in an urban setting. By placing households at the centre of analyses, frameworks have shifted emphasis away from the relationships that poor households have (and can facilitate) with economic, political and social systems at the community, city and national levels (Scoones, 2009). This actor-oriented perspective focuses on how a household's 'endowment' of social capital shapes the opportunities it can access, but it does not go further to integrate this analysis within the local political economy that dictates the most productive forms of social capital and, crucially, who can access these.

Another shortcoming of actor-oriented frameworks is that they have struggled to attribute the centrality of employment within their analyses. In commoditized urban economies, this means they overlook a critical aspect of vulnerability (Gonzalez de la Rocha, 2007). The more a household depends on wage income for access to housing, services and basic needs, the more vulnerable it is to becoming poor or 'more' poor in the face of price rises, income shocks or fluctuations in household dependency ratios (Amis, 1995; Satterthwaite, 1997). Employment must therefore be central to urban poverty analyses, with other characteristics of urban poverty becoming relevant primarily in terms of their influence on a household's chances within the labour market (Amis, 1995; Gonzalez de la Rocha, 2007). This makes understanding access and terms of access to employment critical to our understanding of urban poverty. Actor-oriented frameworks place central emphasis on household agency in this process. Limited skills, qualifications and experience, regular health disruptions and weak social networks all constrain the urban poor's ability to access more or better employment. This implies that households can build, extend and capitalize on these assets to improve labour market prospects (Amis, 1995; Mitlin and Satterthwaite, 2013; Moser, 1998; Rakodi, 1995).

Yet skills, qualifications and experience are far from sufficient for accessing stable and secure employment in urban labour markets. High levels of informality and casualized labour, the limited absorptive capacity of formal and informal labour markets, the mediation of labour markets by intermediaries and strong rigidities in the labour market by social status, education and neighbourhood are all obstacles to better employment outcomes (Amis,

2. Moser's (1998) Asset Vulnerability Framework, for example, conceptualizes social capital as the enabling societal conditions that reduce household vulnerability and increase opportunities within a given urban community (see also Wood, 2005). Baumann (2000) argues that livelihoods frameworks are incomplete without an analysis of politics and power relations, recommending that we include political capital as an endogenous asset. 
1995; Beall, 2004; Mitlin and Satterthwaite, 2013; Opel, 2000; Rakodi, 1995). By focusing on individual and household agency over the social, economic and political structures that underlie struggles for inclusion and exclusion from the labour market and other domains, actor-oriented frameworks overestimate a household's autonomy in devising and mobilizing strategies (Geiser et al., 2011; Gonzalez de la Rocha, 2007; de Haan, 2012; Wood, 2005). Applying a more sociological analysis to urban livelihoods in Dhaka, Wood and Salway (2000) highlight the urban poor's limited room for manoeuvre given their adverse incorporation into patron-client relationships. This article aims to shed more light on the social and political hierarchies that constrain opportunities for social and economic advancement among informal settlement residents. The findings reveal that despite the array of livelihoods strategies deployed to cope with insecurity and advance household interests, the local political economy in which Dhaka's low-income households are situated greatly restricts their prospects for sustained household improvements. Before we reach this analysis, the following section introduces the research in greater detail.

\section{EXPLORING EMPLOYMENT AND LIVELIHOODS IN DHAKA}

Given the centrality of employment to urban livelihoods, the research on which this article is based explored why some household heads could use different forms of employment to support household improvement while others, although in similar jobs, could not. In doing so it compared the experiences and life histories of 'coping' and 'improving' households headed by unskilled labourers, small businessmen and formal sector or skilled workers, ${ }^{3}$ examining the extent to which differences between them were due to the specific livelihoods strategies households deployed or were a result of broader structural influences. The research asks to what extent, for residents of informal settlements in Dhaka, is poverty a result of a lack of financial and non-financial resources or wider political issues? With regard to the latter, the research looked in particular at the social and political hierarchy within Dhaka's informal settlements that controls access to the most lucrative forms of social network. An empowerment framework was used

3. These categories represent the three main categories of jobs that Dhaka's urban poor residents can access. The research design explored household outcomes in the context of community- and city-level influences. It was the household head who was the primary respondent. Typically for households in Dhaka, this meant that respondents for the in-depth interviews were predominantly male. It is outside the scope of this article to engage in a more gendered analysis of poverty, beyond an exploration of female labour mobilization in the next section. As Wood (2005) highlights, patriarchal norms and values impose constraints on women in all dimensions of their lives. Elsewhere I use data from this research to explore women's experiences in the household and labour market in Bangladesh (see Banks, 2013a). 
to ground the analysis, moving away from a depoliticized understanding of urban poverty to one grounded within the local political economy. This helped overcome the tendency for actor-oriented frameworks to downplay poverty's structural features (Narayan and Petesch, 2007), understanding employment and income generation in the context of the broader social relationships determining access to jobs.

The basic finding of the research is that, given the endemic insecurity of urban livelihoods in Dhaka's informal settlements, most household improvements are small, incremental and vulnerable to reversal. There is some, albeit limited, scope for household improvement regardless of the specific job category that provides the main economic support to the household. Whether or not these improvements can be sustained is dependent on the terms of employment secured. Crucially, if a household is outside the distributionary networks of the settlement's leaders, members cannot access employment on terms that will enable them to earn higher wages, qualify for certain allowances and benefits or experience greater job security. A deeper exploration of the social systems governing Dhaka's low-income settlements highlights the constraints that informal governance systems place on opportunities for long-term household improvement.

Four research sites were selected for the research: two in central and two in peripheral Dhaka. Within each geographic location, two neighbouring settlements were chosen. The differentiation between these two sites was their access to water supply: in each pair, one settlement received services through informal channels, while its neighbouring settlement had secured rights to control the legal water supply through the operations of a local NGO. These selection criteria enabled me to disentangle the influence of geographic location and legal service provision on poverty outcomes. The breadth and depth of research methods allowed me to explore experiences and outcomes at the household- and settlement-level. Community mapping and a survey which covered every household within a small geographic area allowed me to build detailed socioeconomic profiles of each settlement. ${ }^{4}$ The core data for analysis were provided by 75 in-depth interviews with heads of 'coping' and 'improving' households across all four settlements. These households were selected on the basis of self-reported mobility statuses from community surveys and constituted a within-case analysis of household heads across the three main employment categories. This disaggregated analysis allowed me to identify and understand differences within groups of similarly employed

4. In three settlements the survey covered an area constituting roughly a quarter of that settlement. The fourth settlement was a new and expanding settlement. As such, it was significantly smaller, allowing the research team to cover the whole community with the same size of survey. High levels of labour mobilization created difficulties in accessing all households. To minimize this, the team returned repeatedly to households to find suitable times for interview. The research took place in 2009; Banks (2010) details the research methodology in full. 
workers, overcoming a tendency within the literature on urban employment to treat certain sectors of the labour market as one homogeneous category (Gonzalez de la Rocha and Latapi, 2008).

The qualitative methods used mean that findings cannot be generalized beyond the four sites, but observations in other settlements in Dhaka indicate that these findings are typical of low-income neighbourhoods (Pryer, 2003; Roy et al., 2013; Wood and Salway, 2000). ${ }^{5}$ While investigating local governance structures was not an explicit part of the research design, the analysis of employment and livelihoods highlighted this as central to social and economic advancement across the four settlements. The range of research methods used - which also included a community mapping exercise, 22 focus groups and participant observation - generated rich insights into social, economic and political dynamics across the four sites. This meant that indepth interviews and outcomes could be contextualized and analysed within each settlement's local political economy. Findings here are strengthened by the author's previous research on urban governance (Banks, 2013b) and by several recent studies into how social and political systems govern land allocation, service delivery and everyday life for informal settlement residents in Bangladesh (Hackenbrock, 2013; Hossain, 2013; Suykens, 2015).

It is important to draw attention to similarities and differences across the four settlements in terms of land, housing and leadership, as these shape how settlements develop and determine the socioeconomic opportunities that are available to residents. Three of the four settlements had high tenancy rates. In both settlements in central Dhaka, housing patterns emerged over 40 years ago when powerful individuals first settled on the land and allocated plots amongst themselves. These consist of small compounds in which an owneroccupier lives, surrounded by tenants in rental rooms around him. ${ }^{6}$ In these two settlements, 66 per cent and 83 per cent of residents rented their housing. Both are situated on public land owned by various government agencies. Owner-occupiers have no formal rights to the land, lacking the land holding numbers (a formal registration certificate) that prove ownership. Both tenants and owner-occupiers are subject to regular eviction pressures that have so far been prevented by court injunctions.

One of the two settlements in peripheral Dhaka emerged through similar processes. Four families settled there 40 years ago, passing down informal ownership of the land to their descendants. All 27 owner-occupiers in

5. With its focus on poverty outcomes among residents of Dhaka's informal settlements, this article does not take into account the nature of urban poverty or opportunities for household improvement among low-income urban residents living in other locations. These other locations include hostels (an option for young women migrating to work in Dhaka's thriving garments industry), markets, their places of work (for domestic workers, security guards, or other house staff), or on the streets.

6. In some cases the informal owner of these plots lives outside the settlement and appoints a house manager from among the tenants to collect rent and manage residents. 
this settlement are related to these original settlers. Over three-quarters (78 per cent) of households were rental tenants. The local leader was fighting for formal recognition of land ownership in court against the government, who claimed it remained public land. The fourth settlement, bordering this site, displays a different residential pattern. This was an emerging settlement located on land owned by the local Ansar camp. ${ }^{7}$ After an eviction nearby, residents relocated here, paying around 5,000 taka to Ansar guards to secure land plots on which to build rooms. ${ }^{8}$ These informal payments did not give them formal land rights, but residents felt that it gave them security from eviction for several years. These arrangements offered opportunities for house ownership that were not available elsewhere. Two-thirds of households here 'owned' their rooms.

\section{URBAN LIVELIHOODS IN DHAKA: STRATEGIES AND LIMITATIONS}

This section explores the livelihoods strategies deployed by 'coping' and 'improving' households across the four communities, which remain similar regardless of whether the household head is engaged in unskilled labour, small business or formal sector work. The four community surveys reveal that the day-to-day lives of Dhaka's urban poor are characterized by endemic insecurity. Households struggle to secure sufficient income to meet the high costs of urban living. As we have seen, in three of the settlements, a large proportion of residents are tenants; they spend between 18 and 22 per cent of their monthly incomes on rent and utilities (Banks, 2012). Combined with food and fuel expenditures only 45 per cent of households break even or have an income surplus each month (ibid.). ${ }^{9}$ The ability to bridge regular income deficits is at the forefront of household struggles, and regular healthcare costs exacerbate financial pressures. If we include average monthly expenditures on healthcare, only one in three households have sufficient income to cover their routine household expenditures (ibid.).

The three strategies which distinguish 'improving' households from 'coping' households across all three employment categories fit neatly into analyses of urban livelihoods. Regardless of their integration into the labour market, households in these four settlements pursue similar livelihoods strategies to protect and promote their interests. They try to mobilize all

7. Ansars are one rank within Bangladesh's security forces.

8. To give an idea of exchange rates: at the time of the research, GBP 1 was equivalent to 108 Bangladeshi taka; in November 2015, GBP $1=119$ Bangladeshi taka; in June 2015, US\$ $1=77$ Bangladeshi taka.

9. This matches findings from other studies of urban livelihoods in Dhaka's informal settlements. Pryer (2003) finds nearly one in three households reporting a 'severe' financial deficit, 30 per cent reporting a 'slight' deficit and over one-third reporting a break-even situation. Only 4 per cent of households reported a slight income surplus, and 0.2 per cent a surplus large enough to save. 
available labour within the household, invest in productive assets, and/or expand their access to finance through savings and loan portfolios. ${ }^{10}$ What differs is the level of stability they achieve through mobilizing these strategies and the reasons why some succeed and others fail. This is where actororiented frameworks become less effective for explaining differences between 'coping' and 'improving' households. As the discussion will show, despite their best efforts to expand the labour force, secure productive assets and accumulate financial capital, most low-income households in Dhaka still face severe challenges balancing incomes and expenditures. This is because, in the majority of cases, these strategies do not lead to higher or more regular incomes, without increasing financial pressures on the household.

Few jobs provide sufficient income for the household head to support household costs single-handedly. Labour mobilization strategies are therefore two-fold: to maximize the household head's income through more regular or higher paid employment, and to supplement this through other members' labour. Household heads try to improve the terms of their existing employment through owning rather than renting their rickshaw, expanding the scale or profitability of their small businesses, or establishing good relationships with their employers and patrons. Household heads also try to move into better options: from unskilled labour into small business or formal sector work, for example. They face obstacles in both quests. Some are agency-related, including limited skills, qualifications and experience, limited capital, advancing age or regular ill health. Others are structural, woven into a hostile labour market characterized by oversaturated markets and intense competition, low wage rates, difficult and unhealthy working conditions, work irregularity and the mediation of the labour market by intermediaries (Opel, 2000; Roy et al., 2013; Wood and Salway, 2000).

Rapidly changing urban labour markets have reduced the central role of adult men as breadwinners across diverse urban contexts (Gonzales de la Rocha, 2007; Kantor, 2009). In Dhaka, too, female employment has become central to urban survival, demonstrating a significant shift in practices that challenge traditional patriarchal ideologies (Banks, 2013a). Wives and daughters are sent to work in Dhaka's garments sector, providing critical contributions to household income. Across the four settlements, 58 per cent of households mobilize female labour. ${ }^{11}$ Yet despite mobilizing all members of working age and ability, labour mobilization strategies rarely secure sufficient or stable incomes. Seasonal gluts in employment create problems in stabilizing income throughout the year, and female employment is subject

10. While there is no space to go into these strategies in depth here, a detailed analysis can be found in Banks (2012).

11. The prevalence of female labour rises with several indicators of insecurity. Female employment increases to 65 per cent in households headed by unskilled labourers, for example, and was also high (64 per cent of households) in communities where social problems of drug addiction and gambling were widespread (Banks, 2013a). 
to regular disruption due to pregnancy and childcare, harassment at work, or with the loss of daughters at marriage. Unless it can be sustained, the mobilization of female labour thus provides a weak foundation for longerterm stability and advancement. Household heads also report that elder sons and daughters do not contribute their full incomes to the household, instead keeping large portions for themselves to cover their own costs, implying that this, too, is an unreliable way of generating significant additional income streams for meeting household costs.

Productive assets offer another means of supplementing wage income. Several 'improving' rickshaw-pullers owned their own rickshaw, increasing their income by removing daily rental fees. High monthly room rents, however, leave little surplus income for saving or investing in productive assets. ${ }^{12}$ Only 12 per cent of tenant households own productive assets, in comparison with nearly 70 per cent of house owners. ${ }^{13}$ For businessmen in particular, comparisons between 'coping' and 'improving' households highlight that productive assets are critical to promoting household improvement. Yet the majority of small businesses lack productive assets and operate at limited scale and profitability in a context of severe competition (Wood and Salway, 2000). Despite small business being seen as a preferable job, across the four sites only one in four households supported by small business report household improvements.

Housing is the most profitable asset. Alongside reducing living costs, if house owners own additional rental rooms they can generate monthly incomes far above the highest paid jobs. Across the four settlements, just under a third of households own their own room (although this average is increased by the predominance of house ownership in the newer settlement in peripheral Dhaka). ${ }^{14}$ Landlords owned between one and 22 rooms. ${ }^{15}$ Those owning

12. Purchasing a rickshaw, for example, costs between 6,000 and 12,000 taka, depending on its age and quality. Although this investment quickly pays for itself in rental savings, it remains prohibitively expensive to most rickshaw-pullers. Daily incomes after rental costs do not allow savings, especially given the uncertainty of household expenditures. As one 'coping' rickshaw-puller in central Dhaka argued, 'Planning [for the future] depends on finances. So with this job, and no savings, how can I plan?'. Short-term efforts to save are quickly negated by income fluctuations or other shocks to income as a result of ill health, rickshaw theft, or rainy season. 'Suddenly I am ill, suddenly my household is doing badly, or suddenly my rickshaw is stolen and I have to repay my garage-owner. We cannot manage savings within our income, and if we can, they are quickly destroyed through these emergencies', explained one focus group of rickshaw-pullers in central Dhaka.

13. Assets referred to here are in addition to the room that they live in themselves, and include rooms rented out to tenants, rickshaws for rent, or equipment for small business.

14. In this newer informal settlement, or bastee, 67 per cent of households owned their room. In the neighbouring site in peripheral Dhaka, only 14 per cent of households owned their room. In central Dhaka, 16 and 33 per cent of households in the two research sites owned their rooms.

15. In the fourth site in peripheral Dhaka, where two-thirds of residents owned their own rooms after informally purchasing land plots from Ansar guards, the majority of households could only afford to purchase their own plot and did not own additional rental rooms. This 
Table 1. Self-reported Assessment of Households' Change in Status (2004 to 2009)

\begin{tabular}{|c|c|c|c|}
\hline & Better & Worse & The Same \\
\hline Site 1 Central Dhaka, no services ${ }^{\mathrm{a}}$ & $26 \%$ & $43 \%$ & $27 \%$ \\
\hline Site 2 Central Dhaka, legal services & $23 \%$ & $51 \%$ & $26 \%$ \\
\hline Site 3 Peripheral Dhaka, no services ${ }^{\mathrm{a}}$ & $12 \%$ & $42 \%$ & $44 \%$ \\
\hline Site 4 Peripheral Dhaka, legal services & $29 \%$ & $35 \%$ & $36 \%$ \\
\hline
\end{tabular}

Note:

a. In two settlements, a handful of respondents answered 'Don't Know'; these rows do not therefore add up to $100 \%$.

Data source: Banks (2010)

in excess of four rental rooms could generate enough income to provide them with the stability necessary for consolidating household improvements over the long-term (Banks, 2012). ${ }^{16}$ This means that the households dominating the housing market in three of the settlements cannot be considered 'poor' in income or asset dimensions, nor, as the following section highlights, in social dimensions. The predominance of house ownership in the emerging settlement in peripheral Dhaka meant that no settlement elite had yet emerged. In the other three settlements, however, between 14 and 33 per cent of households dominated the housing market. This small proportion is symbolic of the small bastee elite that we examine in the following sections.

Households were asked whether they perceived themselves to be 'better', 'worse' or 'the same' compared to five years previously. Table 1 shows the responses. Across the four settlements, between 12 and 29 per cent of respondents reported that their households were 'better' than five years previously; between 35 and 50 per cent reported they were 'worse'; and between 26 and 44 per cent reported they were the 'same'. Only a handful of households can be said to have 'improved' their structural foundations to secure higher and sustained household incomes. Most describe themselves in a precarious state of tanatani, a financial tug-of-war in which incomes and expenditures pull constantly in opposite directions. This means that savings and loans play an important role in consumption-smoothing. High levels of indebtedness and a high prevalence of moneylender loans accompanied by catastrophic repayment terms ${ }^{17}$ indicate that loans are more frequently

meant there was not the same visible wealthy elite here dominating the housing market. The average number of rooms owned here was 1.5 , in comparison with 6.6 rooms in the neighbouring settlement. In the two sites in central Dhaka, the average numbers of rooms owned by landlords were 3.8 and 6.7 .

16. Not all house owners are considered part of the elite. Focus groups argued that landlords owning many rental rooms were not 'real basteebashees (slumdwellers) like us', but recognized that smaller landlords owning up to four rental rooms could also struggle to make ends meet because of the high costs of urban living.

17. These catastrophic repayment terms lock households into never-ending cycles of interest repayment. Households are forced to accept interest rates of between 10 and 30 per cent 
used for coping than investment. Across the four settlements, 82 per cent of households have one or more loans; between 24 and 52 per cent of households have at least one loan from a moneylender. It is no surprise that 'improving' households are less likely to borrow or have loans from moneylenders. Where they do borrow, it is more likely to be from NGOs or interest-free from friends or relatives, providing investment capital rather than emergency finance (Banks, 2012). While improving households also demonstrated the importance of savings in meeting emergency finance needs, only around a third of households could accumulate savings given the financial pressures discussed here.

This section has explored the variety and limitations of livelihoods strategies deployed by Dhaka's informal settlement residents. It reveals a clear hierarchy between house-owners and tenants when it comes to material wealth, security and opportunities for household improvement. The next section explores this dichotomy in more detail, highlighting the close link between economic and social resources. Separating the minority of households that have achieved improvements from the majority who remain unable to do so are critical differences in social networks that allow for capital accumulation over time. This highlights the need to revisit the role and conceptualization of social capital in analyses of urban livelihoods (see below).

\section{THE LOCAL POLITICAL ECONOMY OF DHAKA'S LOW-INCOME SETTLEMENTS}

A deeper understanding of how social networks and local governance structures influence urban poverty is critical, embedding our analysis of urban poverty within the social and political processes that limit access to better incomes, assets, services and employment opportunities. While our focus here is on the local (settlement-level) political economy, we have to contextualize this within the broader institutions and processes of urban governance, including a national and municipal policy framework that neglects the needs and rights of the urban poor (Banks et al., 2011). ${ }^{18}$ This has led to the

of the total capital borrowed each month. This means for a 10,000 taka loan a borrower must find between 1,000 and 3,000 taka in interest repayments each month. To give some indication of the feasibility of this, 1,000 taka would be roughly approximate with monthly rental and utility costs. Capital repayments must be made in large payments of 1,000 or 5,000 taka, making it nearly impossible for borrowers to repay this on top of monthly interest payments. Many households claimed that moneylenders are 'cutting the throats of the poor' through these terms of lending.

18. Banks (2008) provides a systematic analysis of municipal and national governance and how this constricts opportunities for the political participation of the urban poor, leaving them dependent on local leaders and 'problem-solvers'. Banks et al. (2011) give more detail on the reasons underlying this neglect of the urban poor in national and municipal governance, including a rural bias in Bangladesh's PRSP, a lack of coordination among departments 
creation of informal systems of governance that connect informal settlements with the wider city, but in a way that creates and reproduces inequalities within them.

For urban governance to meet the needs of the urban poor requires a system in which their votes count; there also needs to be a pro-poor municipal government that has the capacity to deliver, as well as a dynamic civil society that can work towards an accountable relationship with the state (Devas, 2001). Formal representation for the urban poor in Bangladesh is limited, but does include voting rights in municipal and national elections. Ward commissioners provide the most local level of democratic political representation, acting as a 'gatekeeper' into wider municipal governance. However, ward sizes are large (ranging from 65,000 to 100,000 residents) and ward commissioners have little funding or resources with which to fulfil local development priorities. With no direct mandate for urban poverty reduction, the priorities of the urban poor are pushed to the bottom of the agenda (Banks, 2008, 2013b). ${ }^{19}$ With such large constituencies, ward commissioners and other officials rarely engage directly with informal settlement residents, using politically-affiliated local leaders to manage these relationships. Leaders are supported by a network of strongmen, known as mastaans, to enforce their will. ${ }^{20}$ The government fears that large urban areas controlled by opposition parties will damage their chances of re-election; operating through these leaders minimizes the risks of anti-government movements emerging (Hossain, 2013). In the process, the interests, power and authority of local leaders are protected (Suykens, 2015). ${ }^{21}$ Through these leaders - and their committees and strongmen - the government can manage and control low-income settlements as vote banks, provide alternative forms of 'informal' service provision, ${ }^{22}$ or distribute goods and entitlements such as food

and ministries, the stigmatization of the urban poor as a dirty or criminal underclass and resignation to the fact that tackling urban poverty is 'impossible'.

19. These problems are exacerbated by a lack of decentralization of power and resources to the municipal level. City Corporations do not have effective powers to enact the popular will.

20. Suykens (2015) gives a detailed analysis of complex power relations in an informal settlement in Chittagong. According to Suykens, mastaan figures combine elements of other roles - local leader, businessman or mafia don. They play a key part in enforcing contracts where settlements lack the formal organization or regulations for this, and resort to violence in doing so if necessary. There is a thin line between local leaders and mastaans: some leaders may have been mastaans in the past, some may remain so (Suykens, 2015). But not all mastaans are local leaders.

21. Within settlements on public land, there are political committees for the two main political parties that manage and control activities, resources and space within the settlement. At any one time, one political committee is in control, drawing its power from the government in office at the national level. Power dynamics therefore shift within the settlement in line with changes to the ruling party.

22. Service providers are legally forbidden from delivering services to the residents of informal settlements who lack land-holding numbers. Lacking a formal claim to legal service provision, informal settlement residents are therefore dependent on local businessmen who 
rations or blankets in emergencies (Banks, 2008; Banks et al., 2011). Working with these intermediaries, ward commissioners and other officials have little incentive to be directly responsive towards, accountable to, or inclusive of, settlement residents (Banks, 2008). After elections, ward commissioners have little interaction with residents of informal settlements within their jurisdictions, thus excluding the majority from the wider system of municipal governance. ${ }^{23}$

Unable to assert their rights to secure tenure and adequate services through formal systems, the majority of low-income urban residents are dependent on these influential intermediaries and the relationships they hold with strongmen, elected officials and local and national politicians (Suykens, 2015). These clientelistic relationships have come to dominate the wider forms of participation through which the urban poor in Bangladesh gain access to services and opportunities (Banks, 2008). Patron-client relationships are based on economic structures of exploitation, political structures of domination and ideological structures of consensus and control (Lewis, 2011). The material benefits they offer reinforce political and economic inequalities and strengthen vertical links between elites, authorities and the urban poor (Mitlin and Satterthwaite, 2013). As Wood (2003) highlights, they represent a 'Faustian Bargain', helping low-income households to negotiate insecurity at the long-term cost of their ongoing dependency. There is little scope for challenging the structural and exploitative conditions these relationships impose on their long-term autonomy and well-being (Wood, 2005). Accessing emergency loans from moneylenders or a rickshaw garage-owner may help a household to meet emergency needs, for example, but their high interest rates increase financial pressure on the household long after the emergency is over, locking households into endless cycles of interest repayments. As one 'coping' household head explained, 'my mohajon [moneylender] told me "You are old and not earning much. You cannot repay my capital so you must pay me 30 per cent interest [on the capital borrowed] each month"”.

As we will see below, we cannot understand the strengths and limitations of household livelihood strategies in isolation from the social and political processes that reinforce clientelistic dependencies (Wood, 2005). We must understand the broader implications of these processes on urban livelihoods for informal settlement residents. This requires looking at two distinct strategies of urbanites for substituting for the formal governance functions they lack: those used by vulnerable low-income urban households to achieve a

have the right connections to become informal water and electricity suppliers within the settlement. Accessing water and electricity through these channels, however, comes at high cost and low quality.

23. Mediation through leaders also removes questions of accountability: even where settlement residents are aware that rights are being overlooked or resources not distributed equally, the threat of violence or retribution from leaders and their enforcers is enough to prevent communities from vocalizing their disapproval. 
Figure 1. Defining Characteristics of Social Networks within Different Tiers of a Settlement's Social and Political Hierarchy

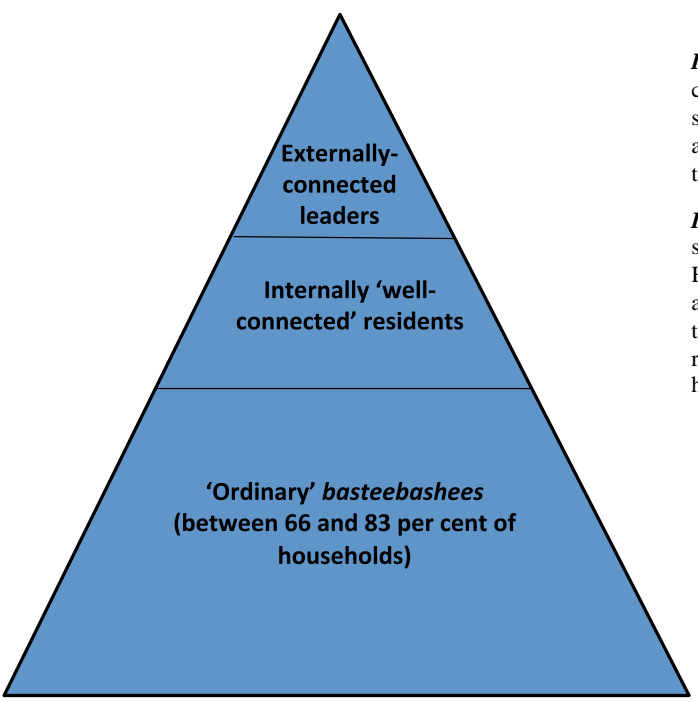

Internal and external connections that constitute accumulation networks. External social connections provide opportunities to access higher and sustained incomes over time.

Internal connections of the 'right' kind to still constitute accumulation networks. Household may not access external resources and opportunities directly, but can still access them on beneficial terms through their good relationships with externally-connected households.

Internal connections that constitute survival networks. Reciprocal networks with other households offer limited resources given near universal resource constraints within this tier. Their connections with upper tiers, through which households access housing, services, or loans, come at a high cost and often exploitative terms.

minimum level of security, and those used by more powerful groups to create personal networks of advantage that secure them greater profits and control (Lindell and Utas, 2012).

Figure 1 offers a crude representation of the informal channels through which rights and entitlements are negotiated in Dhaka's informal settlements. ${ }^{24}$ Access and terms of access are dependent on a household's position within a rigid social hierarchy. A relatively small elite exists at the settlement level with both internal and external social networks. Their external networks connect them with access to resources and opportunities within and outside the settlement. Leaders can consolidate their leadership by rewarding their supporters (including their strongmen and other large landlords in the settlement) and family or kinship networks with the resources and opportunities they access through their external connections. But this is a closed network. For most households, the repercussions of resource scarcity are compounded by the limitations of their accessible social networks. Their social networks are confined to the settlement. Households make considerable efforts to establish and maintain the reciprocal networks and patron-client relationships they need to cope with ongoing livelihoods insecurity. Of course there is

24. This illustrates the social hierarchy within low-income settlements on public land where local power structures emerge. The urban poor living in settlements on private land face different forms of exclusion. Where private landowners develop temporary housing for the urban poor to generate income while land increases in value, they mediate connections with external individuals or authorities and actively prevent their tenants from making connections outside the settlement. See Roy et al. (2013) for more detail. 
greater complexity to these relationships than can be adequately represented in such a diagram, but for the purposes of this analysis, it remains useful to distinguish between these three levels of the social and political hierarchy: those members of the elite with strong external networks; those members of the elite who lack external networks, but can enjoy the benefits of them through their links with the former individuals; and those with neither external connections nor the 'right' internal connections to access resources and opportunities on the same beneficial terms. These hierarchies illustrate the critical difference between those in the upper two tiers with accumulation networks and those at the bottom of the hierarchy who receive limited or exploitative returns through their survival networks. We go on to explore these differences now.

Externally connected leaders take their position at the top of the hierarchy, bringing information, resources and opportunities into the settlement through their powerful connections outside the settlement. Political affiliation is the main source of a leader's legitimacy. Leaders take and relinquish power as their political party is voted into or out of government. Affiliation with the ruling party gives them protection to assert authority over the settlement without risk of repercussion. This, and their network of mastaan enforcers, allows them to use the threat of violence as a form of social control when necessary (Banks, 2008; Hackenbroch, 2013; Hossain, 2013; Suykens, 2015). Close links with police and security services give them additional protection. Rickshaw-pullers and garage owners detailed a highly-organized rickshaw syndicate across the city, in which rickshaw garage-owners have to pay substantial bribes to retrieve stolen rickshaws. ${ }^{25}$ Those running the syndicate are protected by their close links with police and high-powered political contacts. 'No one can do anything', explained one garage-owner, 'People know where the garage [where they operate from] is, but cannot do anything because the leader has the right connections with the authorities'. ${ }^{26}$

25. Thieves masquerading as passengers find ways to make the rickshaw-puller leave the rickshaw unattended, requesting they get change or buy them cigarettes, for example. On return, rickshaw-pullers find their rickshaws gone. This has a destructive impact on rickshaw-pullers and garage-owners, who must pay significant bribes to get them back (each rickshaw has the telephone number of its owner painted on it for this purpose). Several 'coping' businessmen explained how crime had impacted on their businesses and household incomes. As one coping garage-owner told us: 'My garage started with 16 rickshaws. Nine were stolen, and two more were badly damaged. I retrieved four of the stolen rickshaws, but one was stolen again. Now I have only eight rickshaws. When a rickshaw is stolen it costs at least 4,000 taka to get it back. The rickshaw-puller contributes 1,000 taka to this. They are poor, how can I ask them for more?'.

26. In the same central Dhaka settlement where this research took place, residents recounted an experience when the police asked settlement residents to assist them in catching criminals in the settlement. After turning over one criminal - a renowned local leader — to the police, residents did not receive the safety they had been promised. Instead, the criminal was able to bribe himself out of jail. On his return, he tortured the families who had helped seize him and the police would not step in to protect them (Banks, 2008). 
Their legitimacy is further secured by other external connections outside the settlement, including with service providers, elected politicians (at local, municipal and national levels), and local businessmen. ${ }^{27}$ They can distribute the returns from these connections through their networks, generating support from their associates within the settlement.

Leaders facilitate community development by connecting settlements to the wider city, managing community resources and bringing in informal services, job opportunities and resources. These external relationships benefit leaders and their patrons outside the settlement. They constitute resource accumulation networks for leaders, legitimating their leadership and maintaining their control over resources, as well as the settlement's dependence on them. In return for these benefits, the leaders provide a source of social control to politicians, profits to service providers, or reliable labour to businessmen outside the settlements. Those in power decide whether and how these resources benefit residents. Assumptions that leaders have the settlement's collective interests in mind would be misguided. Rather, resources are first used for self-gain and to reward their supporters, further consolidating their power. Households were keen to distance themselves from association with community-based organizations because of this orientation of leaders towards self-gain. '[No, my husband] is a good man, a polite man, he concerns himself with his family only', explained one respondent when asked if anyone was a member of any community organizations. Another described her husband as niriho: a 'simple and honest' man who would not be involved in such activities. As an earlier study of the urban poor's political participation in Dhaka highlights, leaders are seen as a 'necessary evil': they are supported for their role in connecting the settlement to services and political contacts, but feared for their use of extortion and the threat of violence to control settlements (Banks, 2008). Early in the research in central Dhaka, the team was confronted by a local leader demanding to know what help we were bringing to the settlement. While the research was not bringing any direct benefits, residents explained his reaction to us shortly after this run-in. One resident explained why the leader had been so quick to assert his leadership. 'They are the ones demanding help because they are the ones who reap the benefits', he said. 'These big men will capture [any help that comes]. They will say, "we know everyone here and will distribute it across all households", but they don't do this, so the picture remains the same for us'. Here, too, residents explained that resources brought into the community rarely reach the wider community because of the self-interested motivations of local leaders.

27. Suykens (2015) gives detailed insight into the relationships between local landlords in a bastee in Chittagong and elected officials at both the local and national level. These relationships reach right up to ministerial level. His detailed case study of informal land ownership and negotiations illustrates the multiple layers of complex relationships that we cannot go into here. 
A small group of internally well-connected residents constitutes the second layer in the social hierarchy (Figure 1). They lack the external connections for accessing opportunities and resources directly, but their links to local leadership mean their networks are lucrative nevertheless. The rewards they secure through these connections give them solid foundations for long-term household improvement. Accessing jobs through this channel, for example, means job security and higher incomes. One 'coping' household head had invested heavily in skills development after seeing his neighbour reap the rewards of his job as a skilled technician. His neighbour had received a stipend while training and graduated with a permanent contract and large monthly salary of 6,000 taka (which was further increased by a range of allowances). He was unable to achieve a similar level of success or security, however. Without the right social connections he struggled to find an entry point into the sector. He accumulated household debts of 20,000 taka during an unpaid apprenticeship that he hoped would help him to access a similar job. But after training he still struggled to find work. Eventually he was able to find an insecure contract as a day labourer, receiving a daily salary of 200 taka. This salary was the amount his neighbour received as a stipend during his training. Securing only 18 days of work every month resulted in a monthly salary of around 3,600 taka, of which 1,600 taka went towards debt repayment. ${ }^{28} \mathrm{He}$ was not eligible for any allowances. His seemingly rational decision to invest in human capital was misplaced. Lacking the social networks that provide access to external contractors meant it was impossible for him to access the terms of employment he associated with the job. His household was left in a worse situation having accumulated substantial debts without the increased income necessary to repay them.

Another lucrative opportunity for those with the right connections is the ability to become an informal service provider. With legal regulations prohibiting service delivery to informal settlements, political patronage has become a substitute for government services (Banks, 2008). ${ }^{29}$ After leaders negotiate for informal access with water and electricity authorities, they control some of these supplies themselves and award others to businessmen within their networks. The community surveys in central Dhaka revealed five electricity suppliers in one of the settlements. Of these, two were members of settlement-level political committees and a third worked for a government department, highlighting the importance of political links and affiliation. Like room rental, informal service provision offers significant

28. Of the 1,600 taka repayments he made each month, 1,300 taka paid the monthly interest costs and only 300 taka went towards repaying the capital he had borrowed.

29. Banks (2008) illustrates the patronage networks through which party members reward supporters and penalize opposition through service provision. Respondents of one informal settlement in central Dhaka reported that they had been refused a water line when the last government came into power, on the basis that the whole settlement was perceived to have supported the opposition party. 
financial returns, giving the rights to supply low-cost electricity at high prices to residents within their catchment area. Households accessing electricity through these informal channels pay up to three times as much as those accessing it legally (World Bank, 2007).

Connections with local leaders are associated with active political support or kinship and family lines. One 'improving' household head benefited from the rent-free housing he received from his brother, the settlement leader. Before he retired, he (and his two sons) had also benefited from high-paid permanent contracts as skilled technicians through these familial links. Political affiliation offers another entry point into the top tiers of the settlement's social hierarchy, but requires active membership in upper positions of the settlement's political parties. This entails large investments in time and money, putting it beyond the reach of economically insecure households. The experiences of one 'coping' household head illustrate that expensive attempts to break into these circles are not always successful. Through his efforts he had managed to become an electricity supplier to 15 houses, but this was a small number in comparison with nearby suppliers. He explained that 'doing politics' had in fact been bad for his household. He was a voluntary member of the settlement's political committee and it cost him financially to maintain good relationships with senior party figures. He did not receive the financial returns he had expected from this investment. Sitting alongside him, his wife described him as both a bhalo and bhoka man: a good man because he does not abuse political networks for selfgain, but a stupid man because he does not benefit financially from the relationships that are so expensive to maintain. Other financial risks act as an additional disincentive for low-income households to engage in politics, as the experience of one 'coping' businessman illustrates. He reported how bhaki khay (the practice of taking goods on credit without repaying) had depleted his capital during the opposition party's rule: although affiliation with the ruling party protects one's business against this and other crimes while they are in power, it exposes businessmen to the risk of high financial losses when the opposition party takes power and retaliates. ${ }^{30}$

The third opportunity for joining the settlement's economic and social elite is through control of the housing market. Again, however, there are few means through which households can become house owners and landlords. Between 14 and 33 per cent of households control the housing market in three of the settlements, with house ownership passing down through familial lines. House ownership was the norm in the fourth settlement, but this had not yet led to livelihoods stability or improvement: this settlement had the lowest average monthly incomes and the highest prevalence of loans. Households

30. Local mastaans are one group responsible for the practice of bhaki khay. These wellconnected strongmen use their political influence to avoid paying for goods, targeting members and supporters of the opposition party. Businessmen and women must allow this practice to protect their businesses and their personal safety, and to prevent revenge crimes. 
were heavily indebted after losing assets in their recent eviction and taking loans to access land and buy building materials. Furthermore, households only owned one room. This reduced their living costs, but did not generate the additional income necessary for income security. No leadership structures or settlement elite had emerged here, and the settlement depended on the local leader from the neighbouring settlement as its patron. Only 12 per cent of households reported household improvements here, in comparison with 26, 24 and 29 per cent of households in the other three communities (see Table 1).

What we see, therefore, is that the channels through which households can access resource distribution networks are closed for the majority of households who are not linked by blood ties or active political affiliation, for whom opportunities for house ownership are negligible, and for whom economic insecurity forces risk-averse households to focus on employment rather than investing time and income into extending networks that offer financial risks with no guarantee of return.

Using tenancy rates from the community surveys as a rough approximation, we can estimate that between 66 and 83 per cent of households across the three settlements find themselves at the bottom of the hierarchy, dependent on the upper levels of the hierarchy for their access to shelter, services and security. This is similar to the number reporting their households as 'the same' or 'worse' in the three communities (between 70 and 77 per cent). For these households, the repercussions of resource scarcity are exacerbated by the limitations of their social networks. When incomes and expenditures rarely balance, households seek alternative means for smoothing consumption and coping in crises. Neighbours and family can offer small cash or in-kind loans, but their own resource constraints prevent these networks from offering substantial returns. This makes facilitating and maintaining patron-client relationships critical, assisting low-income households to manage uncertainty and improve their access to employment, services, finance and social support. Patron-client relationships rarely lead to major rewards such as new jobs, higher salaries or low-interest investment finance, but do offer some level of protection in crises. For rickshaw-pullers, a good working relationship with garage owners can offer short-term loans on reasonable terms. For one 'improving' household head working as a garments supervisor, his strong relationship with his employer outweighed the time and transport costs associated with a job far from home. This relationship meant he was paid on time and could access emergency interest-free loans from his employer ${ }^{31}$ two forms of support critical to livelihoods security but not widespread. Working closer to home would mean losing this relationship that had taken six years to build.

31. He had recently had to borrow 14,000 taka this way to cover medical costs, which he was able to repay through monthly deductions from his salary. Without this opportunity, he said, 'I would have otherwise had to go to a moneylender and take any interest rate I could get'. 
We must not forget the role that leadership structures play in community development, providing the 'bridging' social capital necessary for facilitating linkages with the larger city (Conning and Kevane, 2002; Jha et al., 2007; Krishna, 2001; Moser, 2008; Platteau, 2004; Woolcock, 1998). This is evident across the four research sites. While sites were selected to explore the influence on poverty outcomes of geographic location and legal access to services, neither of these emerged as the main facilitators of household improvements at the community-level. It was not the case that the two central - or the two peripheral - settlements offered more prospects for household improvement. Rather, one settlement within each location displayed a higher mean income, and this was not influenced by legal access to services. What was common to these two settlements was the presence of local leaders connecting the settlement to external resources and opportunities and facilitating its longer-term development through their social, political and economic networks.

These findings highlight the importance of moving beyond a stock of 'community social capital' to explore how struggles of inclusion and exclusion play out across different groups of households. The importance of leadership and external linkages must be reconciled with recognition of the channels and impact of distributional networks across different groups of households. Exploring the local political economy of Dhaka's low-income communities we see that an unequal distribution of power and resources leaves the majority of residents unable to access the social networks they need to promote long-term stability and advancement. Residents' ability to negotiate and resist leaders and other patrons is severely constrained by their ongoing dependence, their lack of social and economic power, and a threat of violence and retribution. The final section of this article explores the implications of these findings for our understanding of urban poverty. We see that a narrow focus on household livelihoods depoliticizes the concept and analysis of social capital and overestimates the viability of household livelihoods strategies.

\section{LIVELIHOODS LIMITATIONS: THE POLITICAL ECONOMY OF URBAN POVERTY IN DHAKA}

Returning to Wood's (2005) conceptualization of rural livelihoods, we see that the need to reconcile livelihoods analyses with local political economic analyses applies equally to urban Bangladesh. By prioritizing the influence of household agency on developmental outcomes, actor-oriented frameworks do not pay sufficient attention to the local political economy and the constraints on agency it creates. Differences between 'coping' and 'improving' households in Dhaka illustrate that actor-oriented frameworks and livelihoods strategies can be useful tools for investigating different outcomes. But they tell only one part of the story and cannot illustrate the full extent 
of limitations to household agency when it comes to supporting 'coping' households to follow similar paths to improvement. Vertical hierarchies are maintained through the social reinforcement of clientelistic dependencies (Wood, 2003), limiting opportunities for households to establish and extend relationships and, subsequently, achieve greater livelihoods security.

It is in the way they conceptualize social capital that actor-oriented frameworks are most problematic. They struggle to account for the differences in types of social capital that are available to particular types of household, or for the barriers households face to accessing more productive forms of social capital. Social capital has come to be seen as a depoliticized asset that households can draw upon for security, survival and, in some cases, improvement. As these findings illustrate, however, it is not only the amount of social capital in the community that matters. From a household's perspective it is the type of social capital that their networks can generate that influences opportunities and outcomes. There are critical differences between social networks that are informally maintained through reciprocity and those maintained through hierarchical forms of authority and power, including differences in the rewards and resources accessible from these (Wood, 2005). Given the centrality of social connections to longer-term improvement, we must understand these differences when we assess household agency and livelihoods strategies. This analysis is three-fold, and requires (as we have done here) identifying the forms of social capital most important for expanding access to critical resources, the attributes of those who can mobilize the 'right' forms of social capital, and the constraints faced by those who cannot.

Actor-oriented frameworks have relegated to the margins the fact that, as well as an individual asset, social capital is a collective asset that can benefit groups as a whole, often at the cost of others (Cleaver, 2005; Harriss and de Renzio, 1997; Putzel, 1997). Wood (2005) highlights the 'logical misconception' in the understanding of social capital as the resources that households can draw upon in their livelihoods strategies. We must assess social capital in relation to the broader networks that enable or prevent these resources from being deployed, distributed and capitalized upon. Analyses of livelihoods may have accounted for the role of social capital in livelihoods strategies, but have not looked in sufficient detail at the critical differences between households with accumulation networks vis-à-vis those with survival networks. While earlier theoretical literature defined social capital as a source of social control via community structures and mechanisms (Cleaver, 2005; DeFilippis, 2001; Fine, 1999; Harriss and de Renzio, 1997; Krishna, 2002; Portes and Landolt, 2000; Woolcock, 1998), this has been lost in popular frameworks for understanding poverty and livelihoods. Consequently, actor-oriented frameworks cannot deliver insight into the systemic risks faced by low-income urban residents and fail to recognize the magnitude of obstacles they face in extending and capitalizing on their assets. 
Our analysis in Dhaka highlights the importance of settlement-level structures and hierarchies in shaping individual and settlement outcomes. Despite connecting settlements to external resources and opportunities, community leadership has a strong vested interest in keeping distribution networks closed. Expanding access to resources and entitlements would limit their personal gains, reduce community dependence, and undermine their social, political and economic power. Instead they are incentivized to prevent outsiders from breaking into or circumventing hierarchies in order to maintain power and wealth. Virtually no channels exist through which low-income urban households in Dhaka can extend their networks into the upper levels of the hierarchy to accumulate the social resources they need for greater livelihoods security.

\section{CONCLUSIONS}

The findings presented here reveal that, despite the array of livelihoods strategies deployed to cope with insecurity and advance household interests, the local political economy greatly restricts opportunities for long-term household improvement for the majority of informal settlement residents. We see the precarious situation in which the majority of Dhaka's low-income households find themselves and the limited opportunities available for more secure livelihoods. Incomes and expenditures rarely balance against the high costs of urban living and low and irregular incomes. Social networks play an important role in bridging income deficits, but returns to networks are limited for most households given the similarly resource-constrained households that make up their reciprocal networks and their exploitative integration into patron-client relationships. Clientelistic relationships offer a measure of security by expanding access to shelter, services and finance, but they do so on exploitative terms, maximizing personal returns for patrons and locking households into ongoing insecurity. As a result, where household improvements do occur for households at the bottom of social and political hierarchies, they tend to be small, incremental and vulnerable to reversal.

Another group of households illustrates a different trajectory. Within three of the four settlements there exists a small elite whose domination of the housing market and service provision generates large incomes. These households cannot be defined as 'poor' but remain in the settlement because of the power and resources they can accumulate through their positions. Falling within these categories are leadership figures and their close networks of family, political supporters and mastaans (or enforcers). With the distribution of resources and opportunities confined to the upper tiers of this social hierarchy, households outside these networks cannot tap into the accumulation networks that provide opportunities for longer-term improvements.

What can we learn from the experiences of these different groups? We see that actor-oriented frameworks focusing on livelihoods are more 
useful for descriptive than prescriptive purposes. Comparing experiences of 'coping' and 'improving' households reveals their ability to differentiate between different livelihoods strategies and developmental outcomes. But in focusing on the experiences and outcomes of urban poverty rather than its root causes, they fail to capture the structural constraints placed on household livelihoods. Crucially they view a household's 'stock' of social capital independently of social and political structures within the settlement and how these shape unequal access to resources, opportunities and information among residents. This has important implications, as what may seem like rational household investments have a high probability of limited returns unless a household has the right social connections to make them work. Unless power structures are taken into account, programmes for urban poverty reduction risk elite capture and may deepen existing inequalities (Mitlin and Satterthwaite, 2013; Patel, 2013; de Wit and Berner, 2009). When social and political structures place restriction on access to assets and livelihoods, programmes must look beyond asset-building to find ways of overcoming restrictions on access and agency (Geiser et al., 2011; Satterthwaite and Mitlin, 2014; Stephens, 2011). This makes urban poverty reduction inextricable from more effective and inclusive urban governance (Satterthwaite and Mitlin, 2014).

In attempting to reconcile the relative roles of household agency and structural constraints on opportunities for household improvement in Dhaka's informal settlements, these findings highlight that our understanding of urban poverty - and our attempts to overcome it — must move beyond a narrow focus on assets to incorporate the structural obstacles facing the urban poor at the household- and settlement-level. Are households 'poor' and unable to devise sufficient livelihoods strategies to survive today and to do better tomorrow? Yes, but this tells only part of the story and recognizes only part of the problem. Actor-oriented frameworks may help us to identify the poor, but they fail to capture poverty's social and political roots. Crucially, they cannot capture the local political economy that constrains the efforts that most informal settlement residents make to improve their long-term well-being. The social reinforcement of clientelistic dependencies excludes most households from the social resources most conducive to long-term stability and improvement. This continued dependence has significant implications for a household's medium- to long-term prospects and for patterns of increasing inequality within Dhaka's low-income urban settlements.

\section{REFERENCES}

Amis, P. (1995) 'Making Sense of Urban Poverty', Environment and Urbanization 7(1): 145-58. Banks, N. (2008) 'A Tale of Two Wards: Political Participation and the Urban Poor in Dhaka, Bangladesh', Environment and Urbanization 20(2): 361-76. 
Banks, N. (2010) 'Employment and Mobility among the Urban Poor in Dhaka, Bangladesh'. $\mathrm{PhD}$ thesis, University of Manchester.

Banks, N. (2012) 'Urban Poverty in Bangladesh: Causes, Consequences and Coping Strategies'. BWPI Working Paper No. 178. Manchester: University of Manchester.

Banks, N. (2013a) 'Female Employment in Dhaka, Bangladesh: Participation, Perceptions, and Pressures', Environment and Urbanization 25(1): 95-109.

Banks, N. (2013b) 'The Urban Governance Conundrum: Meeting the Challenge of Poverty Reduction in Urban Areas', in S.M. Aminuzzaman, R. Khair and I. Basu (eds) Governance at Crossroads: Insights from Bangladesh, pp. 181-200. Dhaka: Institute of Governance Studies.

Banks, N., M. Roy and D. Hulme (2011) 'Neglecting the Urban Poor in Bangladesh: Research, Policy and Action in a Context of Climate Change', Environment and Urbanization 23(2): 487-502.

Baumann, P. (2000) 'Sustainable Livelihoods and Political Capital: Arguments and Evidence from Decentralisation and Natural Resource Management'. ODI Working Paper No. 136. London: Overseas Development Institute.

Beall, J. (1995) 'Social Security and Social Networks among the Urban Poor in Pakistan', Habitat International 19(4): 427-45.

Beall, J. (2004) 'Surviving in the City: Livelihoods and Linkages of the Urban Poor', in N. Devas et al. (eds) Urban Governance, Voice and Poverty in the Developing World, pp. 53-67. London and New York: Earthscan Publications.

Beall, J. and N. Kanji (1999) 'Households, Livelihoods and Urban Poverty'. Urban Governance, Partnership and Poverty Theme Paper No. 3. Birmingham: University of Birmingham.

Bebbington, A. (1999) 'Capitals and Capabilities: A Framework for Analysing Peasant Viability, Rural Livelihoods and Poverty', World Development 27(12): 2021-44.

Carney, D. (1998) Sustainable Rural Livelihoods: What Contribution Can We Make? London: Department for International Development.

Carter, M.R. (2007) 'Learning from Asset-based Approaches to Poverty', in C.O.N. Moser (ed.) Reducing Global Poverty: The Case for Asset Accumulation, pp. 52-61. Washington, DC: The Brookings Institution.

Cleaver, F. (2005) 'The Inequality of Social Capital and the Reproduction of Chronic Poverty', World Development 33(6): 893-906.

Conning, J. and M. Kevane (2002) 'Community-based Targeting Mechanisms for Social Safety Nets: A Critical Review', World Development 30(3): 373-94.

DeFilippis, J. (2001) 'The Myth of Social Capital in Community Development', Housing Policy Debate 12(4): 781-806.

Devas, N. (2001) 'Does City Governance Matter for the Urban Poor?', Planning Studies 6(4): 393-408.

van Dijk, T. (2011) 'Livelihoods, Capitals and Livelihoods Trajectories: A More Sociological Conceptualisation', Progress in Development Studies 11(2): 101-117.

Farrington, J., T. Ramasut and J. Walker (2002) 'Sustainable Livelihoods Approaches in Urban Areas: General Lessons, with Illustrations from Indian Cases'. ODI Working Paper No. 162. London: Overseas Development Institute.

Fine, B. (1999) 'The Developmental State is Dead - Long Live Social Capital?', Development and Change 30(1): 1-19.

Geiser, U. et al. (2011) 'Access to Livelihood Assets: Inclusion, Exclusion, and the Reality of Development Interventions', in U. Wiesmann and H. Hurni (eds) Research for Sustainable Development: Foundations, Experiences and Perspectives, pp. 313-30. Bern: Swiss National Centre of Competence in Research (NCCR), Geographica Bernensia.

Gonzalez de la Rocha, M. (2007) 'The Construction of the Myth of Survival', Development and Change 38(1): 45-66.

Gonzalez de la Rocha, M. and A.E. Latapi (2008) 'Choices or Constraints? Informality, Labour Market and Poverty in Mexico', IDS Bulletin 39(2): 37-47. 
de Haan, A. (1997) 'Urban Poverty and its Alleviation: Introduction', IDS Bulletin 28(2): 1-8.

de Haan, L. (2012) 'The Livelihood Approach: A Critical Exploration', Erdkunde 66(4): 34557.

de Haan, L. and A. Zoomers (2005) 'Exploring the Frontier of Livelihood Research', Development and Change 36(1): 27-47.

Hackenbroch, K. (2013) 'Negotiating Public Space for Livelihoods: About Risks, Uncertainty and Power in the Urban Poor's Everyday Life', Erdkunde 67(1): 37-47.

Harriss, J. and P. de Renzio (1997) 'Policy Arena: Missing Link or Analytically Missing? The Concept of Social Capital: An Introductory Bibliographic Essay', Journal of International Development 9(7): 919-37.

Hossain, S. (2013) 'The Informal Practice of Appropriation and Social Control: Experience from a Bosti in Dhaka', Environment and Urbanization 25(1): 209-24.

Jha, S., V. Rao and M. Woolcock (2007) 'Governance in the Gullies: Democratic Responsiveness and Leadership in Delhi's Slums', World Development 35(2): 230-46.

Jones, G.A. and S. Corbridge (2010) 'The Continuing Debate about Urban Bias: The Thesis, Its Critics, Its Influence, and Implications for Poverty Reduction', Progress in Development Studies 10(1): 1-18.

Kantor, P. (2009) 'Women's Exclusion and Unfavourable Inclusion in Informal Employment in Lucknow, India: Barriers to Voice and Livelihood Security', World Development 37(1): 194-207.

Krishna, A. (2001) 'Moving from the Stock of Social Capital to the Flow of Benefits: The Role of Agency', World Development 29(6): 925-43.

Krishna, A. (2002) Active Social Capital: Tracing the Roots of Development and Democracy. New York and Chichester: Columbia University Press.

Lewis, D. (2011) Bangladesh: Politics, Economy and Civil Society. Cambridge: Cambridge University Press.

Lindell, I. and M. Utas (2012) 'Networked City Life in Africa: Introduction', Urban Forum 23(4): 409-14.

Meikle, S., T. Ramasut and J. Walker (2001) 'Sustainable Urban Livelihoods: Concepts and Implications for Policy'. Development Planning Unit Working Paper No. 112. London: University College London.

Mitlin, D. and D. Satterthwaite (2013) Urban Poverty in the Global South: Understanding Scale and Nature. London and New York: Routledge.

Moser, C.O.N. (1998) 'The Asset Vulnerability Framework: Reassessing Urban Poverty Reduction Strategies', World Development 26(1): 1-19.

Moser, C.O.N. (2008) 'Assets and Livelihoods: A Framework for Asset-based Social Policy', in C.O.N. Moser and A.A. Dani (eds) Assets, Livelihoods and Social Policy, pp. 43-81. Washington, DC: The World Bank.

Narayan, D. and P. Petesch (2007) 'Agency, Opportunity Structure, and Poverty Escapes', in D. Narayan and P. Petesch (eds) Moving Out of Poverty: Cross-Disciplinary Perspectives on Mobility, pp. 1-44. Washington, DC: Palgrave Macmillan and the World Bank.

Opel, A.E.A. (2000) 'The Social Content of Labour Markets in Dhaka Slums', Journal of International Development 12(5): 735-50.

Patel, K. (2013) 'A Successful Slum Upgrade in Durban: A Case of Formal Change and Informal Continuity', Habitat International 40: 211-17.

Platteau, J.-P. (2004) 'Monitoring Elite-Capture in Community-Driven Development', Development and Change 35(2): 223-46.

Portes, A. and P. Landolt (2000) 'Social Capital: Promise and Pitfalls of its Role in Development', Journal of Latin American Studies 32(2): 529-47.

Pryer, J.A. (2003) Poverty and Vulnerability in Dhaka Slums: The Urban Livelihoods Study. Aldershot and Burlington, VT: Ashgate Publishing Ltd.

Putzel, J. (1997) 'Accounting for the "Dark Side” of Social Capital: Reading Robert Putnam on Democracy', Journal of International Development 9(7): 939-49. 
Rakodi, C. (1995) 'Poverty Lines or Household Strategies? A Review of Conceptual Issues in the Study of Urban Poverty', Habitat International 19(4): 407-26.

Rakodi, C. (1999) 'A Capital Assets Framework for Analysing Household Livelihoods Strategies: Implications for Policy', Development Policy Review 17(3): 315-42.

Roy, M., D. Hulme and F. Jahan (2013) 'Contrasting Adaptation Responses by Squatters and Low-income Tenants in Khulna, Bangladesh', Environment and Urbanization 25(1): 157-76.

Satterthwaite, D. (1997) 'Urban Poverty: Reconsidering its Scale and Nature', IDS Bulletin 28(2): 9-23.

Satterthwaite, D. and D. Mitlin (2014) Reducing Urban Poverty in the Global South. London and New York: Routledge.

Scoones, I. (2009) 'Livelihoods Perspectives and Rural Development', The Journal of Peasant Studies 36(1): 171-96.

Stephens, C. (2011) 'Revisiting Urban Health and Social Inequalities: The Devil Is in the Detail and the Solution Is in All of Us', Environment and Urbanization 23(1): 29-40.

Suykens, B. (2015) 'The Land that Disappeared: Forceful Occupation, Disputes and the Negotiation of Landlord Power in a Bangladeshi Bastee', Development and Change 46(3): 486-507.

de Wit, J. and E. Berner (2009) 'Progressive Patronage? Municipalities, NGOs, CBOs and the Limits to Slumdwellers' Empowerment', Development and Change 40(5): 927-47.

Wood, G. (2003) 'Staying Secure, Staying Poor: The "Faustian Bargain"”, World Development 31(3): 455-71.

Wood, G. (2005) 'Poverty, Capabilities and Perverse Social Capital: The Antidote to Sen and Putnam?', in I. Alam Khan and J. Seeley (eds) Making a Living: The Livelihoods of the Rural Poor in Bangladesh, pp. 1-33. Dhaka: University Press Limited.

Wood, G. and S. Salway (2000) 'Introduction: Securing Livelihoods in Dhaka Slums', Journal of International Development 12(5): 669-88.

Woolcock, M. (1998) 'Social Capital and Economic Development: Toward a Theoretical Synthesis and Policy Framework', Theory and Society 27(2): 151-208.

World Bank (2007) 'Improving Living Conditions for the Urban Poor'. Bangladesh Development Series No. 17. Dhaka: World Bank.

Wratten, E. (1995) 'Conceptualizing Urban Poverty', Environment and Urbanization 7(1): 1138.

Nicola Banks (e-mail: Nicola.banks @ manchester.ac.uk) is an ESRC Future Research Leader and Research Fellow at the Global Development Institute, University of Manchester, UK. Alongside urban poverty and employment, her recent research interests include NGOs and civil society and youth development. Her current research explores young people's experiences of urban poverty and inequality in Tanzania. 